\title{
Comment
}

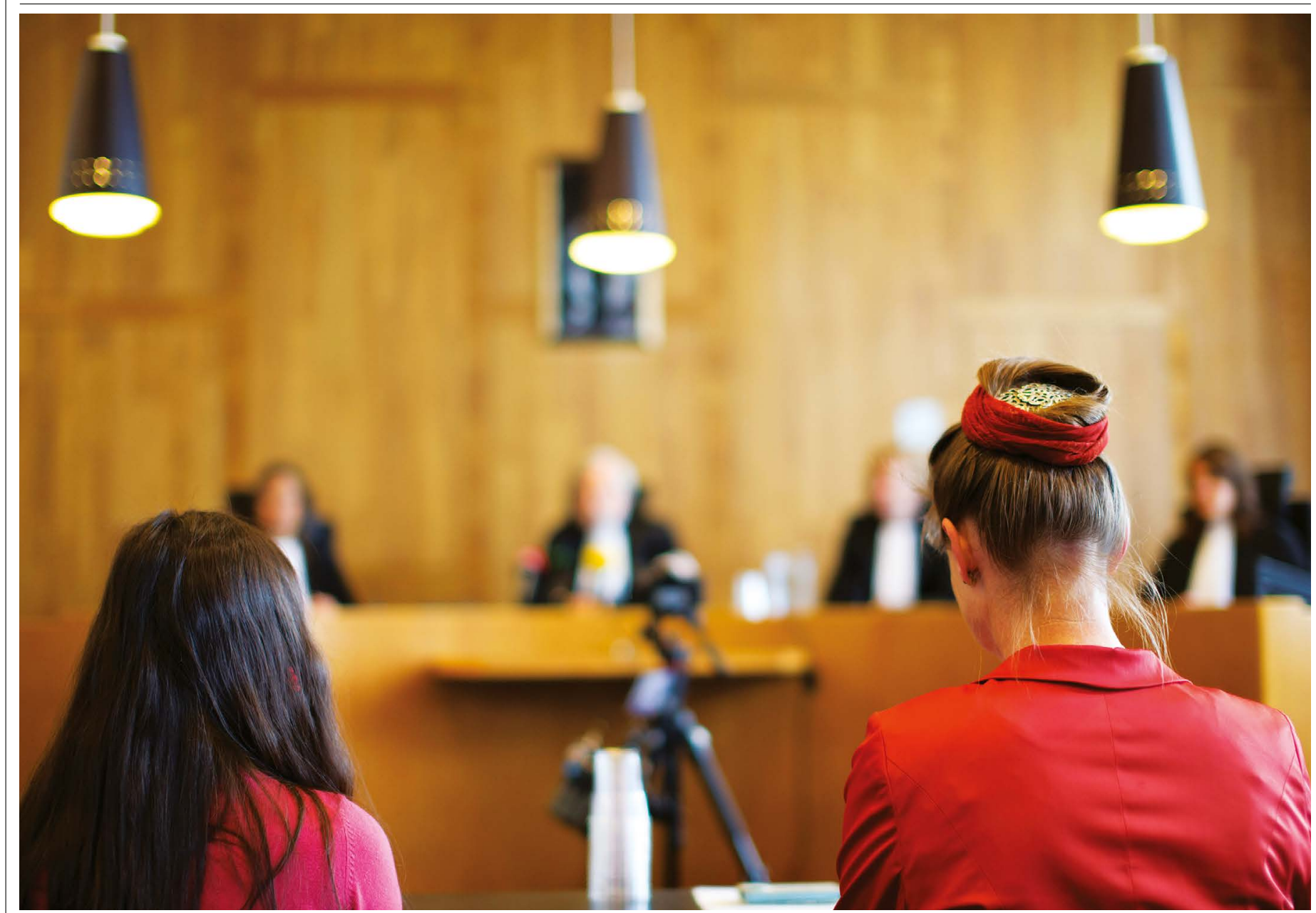

The Urgenda Foundation's co-founder Marjan Minnesma (right) and an 11-year-old co-plaintiff wait for a verdict in the Dutch appeals court in 2015.

\section{Not slashing emissions? See you in court}

\section{Marjan Minnesma}

\section{A pioneer in sustainable} innovation explains why she has spent the past decade fighting the first lawsuit to force a government to act on global heating. live in a nation where more than one-quarter of the land is already below sea level. For much of the past decade, I've been on a journey for climate justice. With 886 of my fellow Dutch citizens, the Urgenda Foundation that I co-founded brought the first lawsuit aiming to find a national government guilty of failing to safeguard its people from the ravages of climate change. We have won repeatedly, at several levels of the court.

Our final win in the Supreme Court of the Netherlands in The Hague on 20 December is a fitting end to a watershed year for civil action on global heating (this article has been updated with the outcome). The case has inspired other national lawsuits that - along with those against corporations and investors - are creating a burgeoning toolkit of environmental jurisprudence. Together, these servenotice on contributors to the world's still-growing emissions that their inaction is no longer defensible.

In 2011 I read Revolution Justified by lawyer Roger Cox (who later acted with lawyer Koos van den Berg for Urgenda in the first court). In the book, Cox argued that catastrophic climate change is a major threat to us and our children, and that governments are not working to prevent it. One of the few democratic ways to make states act, he suggested, is through the legal system.

What if judges read the facts? It would probably be obvious to them that climate change is a clear threat. Might they rule that 'not acting' is hazardous negligence that breaches a government's duty of care towards its citizens? 
That's certainly how I felt. I had been at the first Conference of the Parties to the United Nations Framework Convention on Climate Change (UNFCCC) in Berlin in 1995. The convention was the focus of my law thesis. In the intervening decades of trying to effect change as a scholar and champion of sustainable innovation, I'd also had three children. With every passing year of empty promises, growing greenhouse gases and rising temperatures, my attitude shifted from cerebral problem-solving to worrying for their future. I now give many speeches, around one-third of which are about the problem and two-thirds about solutions. But, most of all, I like starting projects that seem impossible, and finishing them to leave something concrete.

I decided to bring a lawsuit to force the Dutch government to do what it had said for years was necessary - namely, to reduce the emissions of greenhouse gases by between 25 and $40 \%$ by the end of 2020, compared to 1990 levels.

\section{Laggard's letter}

You can start a court case only if you have first tried to reach your goals in other ways. So, in November 2012, Urgenda organized a public seminar close to where the parliament of the Netherlands meets, in The Hague. In theory, the parliamentarians who visited could run straight back to the ongoing debate that day and demand of the government what we asked for.

Presenters that day included the outspoken US climate scientist James Hansen, who is now assisting in several court cases brought by groups of young people in the United States and Norway. Another was Urgenda co-founder Jan Rotmans of the Netherlands National Institute for Public Health and the Environment (RIVM). He built the first integrated climate-assessment model, IMAGE, which has been used in international climate negotiations. The audience included politicians, members of the press and engaged citizens, to whom we explained the dangers of doing nothing and the overwhelming evidence of the severe effects of humans' greenhouse-gas emissions on living conditions.

The seminar had little effect.

That month, we wrote a letter to the Dutch government demanding a $40 \%$ reduction of greenhouse-gas emissions by 2020 . We got a friendly letter back. The government agreed that climate change is a severe problem and that it needed to take action. But, the government wrote, it "did not want to be a frontrunner", claiming that such an approach could dent prosperity and businesses and raise carbon dioxide levels as a result.

This was richly ironic coming from a worldclass laggard in sustainable energy. The Netherlands' international reputation for being 'green' is thanks to cycling and recycling. When it comes to climate change, it talks a lot and does little.

At the time, out of the 27 nations of the
European Union, only Luxembourg and Malta generated less energy from renewables than did the Netherlands. Owing to its rich reserves of fossil fuels in offshore natural-gas fields, as well as its massive ports, chemical industries, agriculture and use of coal, the Netherlands was listed 34 th of the world's roughly 200 countries in the league table of net emissions that year more than $80 \%$ of all countries emitted less. In the most recent league table, from 2015, it is in 40th place. Looking at the biggest emitters of 2014-16 in absolute terms, the Netherlands was in the top ten for emissions per person, higher than China and way above India.

Suggesting that the nation is 'too small to act', as the state argued in court in April 2015, implies that most countries of the world should also do nothing.

\section{Round one}

In mid-December 2012, the Urgenda Foundation decided to sue the government. We invented 'crowd pleading': a cross between crowd funding and citizen science. We asked people tojoin and help us to look for arguments in court cases all over the world. The foundation gathered the 886 co-plaintiffs, all Dutch citizens, including children - the youngest of whom was 5 years old when we began. On 20 November 2013, we handed in the summons to the front desk of

\section{"People were yelling, crying, applauding and hugging. Hardly anybody had expected we would win."}

the Supreme Court in The Hague, demanding a $40 \%$ reduction of greenhouse-gas emissions by 2020 , or - if this was not possible - at least $25 \%$ compared to 1990 levels.

After several rounds of written documents with arguments from us and from the Dutch state, we were called to a hearing at the District Court of The Hague in April 2015. Our hundreds of co-plaintiffs and attendant media could not fit into the court buildings. We produced our own live stream so people could watch together in buildings nearby and follow it at home from their computers. At the end of that day, the judges said they would give their verdict on 24 June 2015 - my 15th wedding anniversary.

We hoped we'd win, but we were not sure at all. We put our chances at perhaps 50\%. I never doubted our arguments, but we didn't know whether the judges would have the time and willingness to dive deep enough into the science of climate change.

At10 a.m. on 24June we were again in court, to hear the short summary of the three judges on our case. I sat at the front of the room watching the judges and trying to tweet the main conclusions. Halfway through the summary, I stopped tweeting because I started to realize that the judges were following our line of reasoning. I glanced at the lawyers to check whether I was right. They were concentrating too hard to catch my eye.

The judges agreed that the Dutch government had breached its duty of care by taking insufficient measures to prevent dangerous climate change impairing the living conditions of its people. They based their arguments on tort law (also called civil law) and the doctrine of hazardous negligence. Because the government had signed many documents from the UNFCCC and the European Union declaring that industrial countries should reduce greenhouse gases by between 25 and $40 \%$ in 2020 , the judges stated that the Netherlands should at an absolute minimum reduce emissions by $25 \%$. Perhaps $40 \%$ is necessary, they declared, but the upper bound is at the government's discretion.

A second after the judges left the court room, it erupted withjoy. People were yelling, crying, applauding and hugging. Hardly anybody had expected we would win.

The verdict was announced in Dutch and English simultaneously, which helped to spread the word. In half an hour, the news was all over the world. We were overwhelmed by the reactions. Calls flooded in from people from Canada to New Zealand. Some were crying on the phone, saying that they had almost given up, but now had hope again.

For Urgenda, the court case changed a lot. Begun in 2007 at the Erasmus University in Rotterdam, the foundation (now based in Amsterdam) had been a non-governmental organization that mainly worked on solutions to climate change for the Netherlands. In 2008, for instance, we imported the first electric vehicles from Norway and sold them to cities such as Amsterdam, while helping to create a network of charging stations. We kick-started the growth of solar power in the Netherlands by organizing the first collective buying initiative in Europe for solar panels and inverters. Our project 'We Want Sun' purchased 50,000 panels, which at the time brought down the prices for rooftop solar installations in the nation by one-third.

After the win, we were framed by journalists and many others as climate activists. They didn't mean it as a compliment. But I took it as one: an activist is one who acts, just as we'd always done. We are still working on climate solutions, but many know us only from the climate case.

\section{Round two}

In September 2015, the government lodged an appeal with the court in The Hague, despite a spontaneous international campaign begging it not to - including messages from celebrities such as actor Mark Ruffalo (who has played the Hulk since 2012) and the model Cameron Russell. So began two years in which our lawyer, Koos van den Berg, produced hundreds of pages with more arguments to convince the 


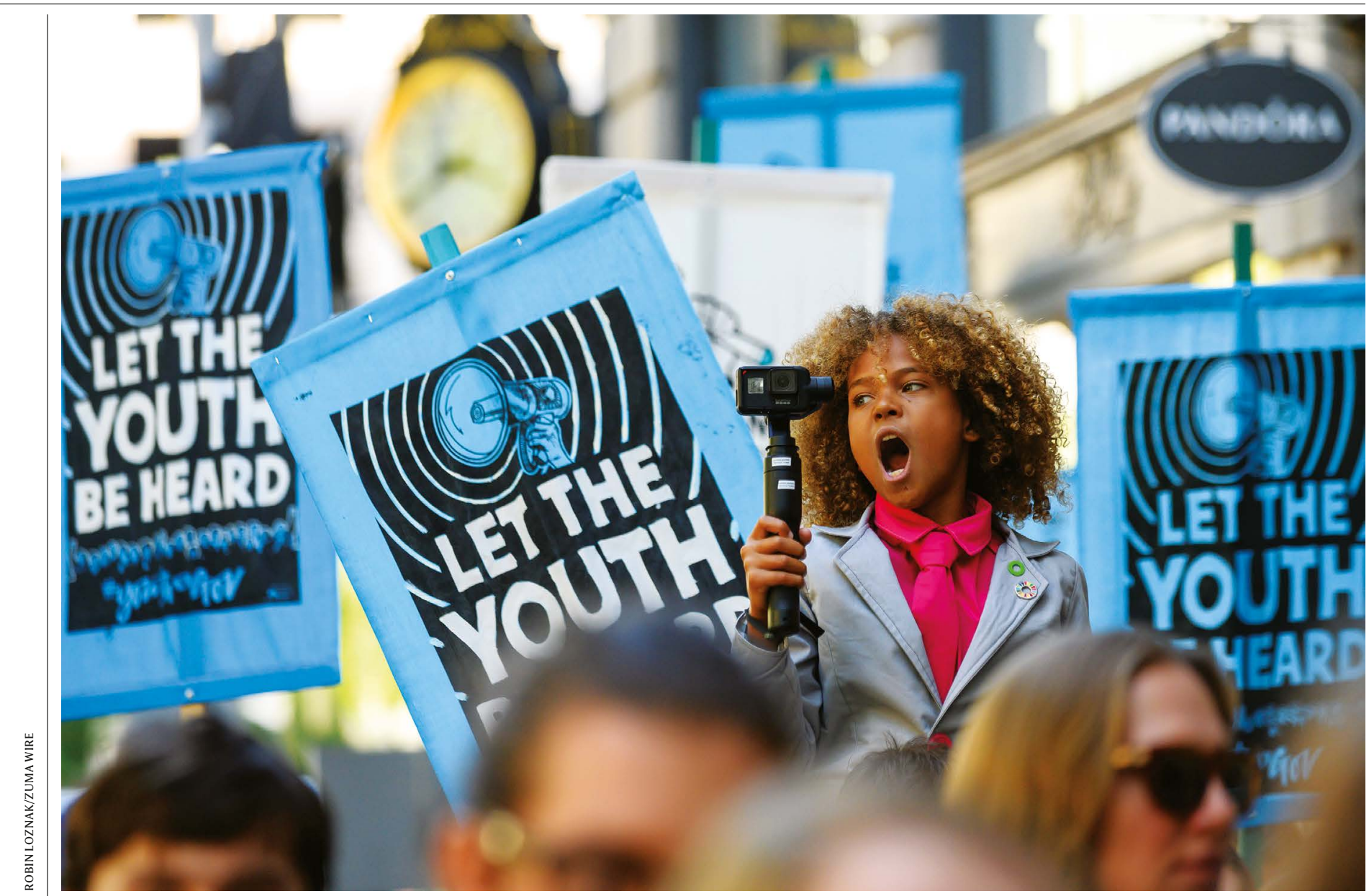

Supporters of a US climate-change lawsuit brought by 21 young people joined a rally in Oregon in June 2019.

appeals court. The second verdict came in October 2018, and again we won! All 29 grounds of appeal from the state were declined.

Better still, this day in court was even more damning for our government (and potentially others) than the first. The district court had ruled that the citizen suit could not base arguments on the European Convention on Human Rights because it was brought by an organization (the Urgenda Foundation) rather than by a human - notwithstanding that its co-plaintiffs numbered hundreds of people. The Court of Appeal disagreed. It declared that the Dutch government is obliged, under articles 2 and 8 of the European Convention on Human Rights, to protect inhabitants by reducing emissions by $25 \%$ by 2020 . So now we had two duties of care, one from tort law and one based on human rights (a higher-order law).

\section{Round three}

Shortly after the second verdict, the government appealed again, this time to the Supreme Court of the Netherlands. This court always takes independent legal advice before ruling, normally from one person. In this case, everything was out of the ordinary, so two advisers were called upon: the deputy procurator general and the advocate general.

On 13 September this year, they delivered their advice: to uphold the earlier judgments. In $80 \%$ of cases, the Supreme Court follows the guidance it is given. But this journey has taught us to brace for surprises.

Meanwhile, six years have elapsed since we filed the case calling for action by 2020 . Although the 2015 judgment spurred the state to set a more ambitious climate policy for 2030 , little was done to meet the 2020 target. The government simply assumed that the judgment would be overturned on appeal. After the second win, that attitude finally changed. To implement the 2020 target, the government has taken measures to close one of the nation's five coal-fired power plants, and has launched new subsidies for energy-saving activities and renewable energy. But with current national emissions reduced by only $15 \%$ from 1990 levels so far, a large gap still remains.

To provide a road map for change, Urgenda published a plan on 24June - the fourth birthday of the first verdict (seego.nature.com/345d4zr; in Dutch). It included more than 700 organizations, including paper manufacturers, farmers, local sustainable-energy co-operatives and large environmental organizations. It set out 40 measures for reducing greenhouse gases by $25 \%$ from 1990 levels by the end of 2020. These included driving at 100 instead of 130 kilometres per hour, raising water levels in nature reserves and energy-saving options for the health and industrial sectors. The foundation later added another ten measures.

So there are now 50 ways for the government of the Netherlands to make up for its failure to protect its citizens from warming of more than $1.5^{\circ} \mathrm{C}$, as the judges of the Supreme Court decreed on 20 December that it must. The 700 partners are poised to help, once the government delivers the money and support that are needed.

It has been a long, hard road, with many ups and downs for the whole team, from tense discussions to nights without sleep. But I'm glad we stayed the course and inspired others around the world to say to their leaders: step up.

\section{The author}

Marjan Minnesma is co-founder and director of the Urgenda Foundation in Amsterdam, which this year received an honorary doctorate as an institute from the University Saint-Louis in Brussels. She lectures at many universities and is a board member of the energy co-operative $\mathrm{OM}$ / new energy in Amsterdam, the Netherlands.

e-mail: marjan.minnesma@urgenda.nl Twitter: @marjanminnesma 


\section{Update}

On 20 December 2019, the Supreme Court of the Netherlands ruled that the judgment of the Court of Appeal should be upheld, ordering the Netherlands to lower its greenhouse-gas emissions by at least $25 \%$ by the end of 2020 , compared to 1990 levels. The article has been updated to reflect this. 